\title{
CONCEPT OF BOUNDING AND BONDAGE IN SHASHI DESHPANDE'S THE DARKS HOLDS NO TERRORS
}

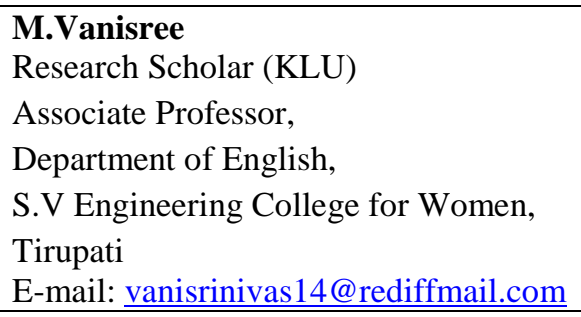

\section{Dr. G.Mohana Charyulu}

Associate Professor,

Dept. of English, K L University,

Andhra Pradesh,

India
Indian women novelists have turned towards the woman's world with great introspective intensity and authenticity. They have instigated a voyage within to explore the private consciousness of their women characters and to measure them. Shashi Deshpande, the living dynamic Women writers in Indian English Literature occupies a prominent position. She delineates the middle class educated women to show that what man has made of woman. She has treated the typical Indian themes very sensitively and has portrayed the contemporary middle-class women with rare competence. Her novels reflects an ongoing process of problematizing life's conflicts and compromises, resolutions and irresolution's, ironies and affirmations, triumphs and tragedies and so on.

Her first novel 'The Dark Hold No Terrors' has been translated into German and Russian languages. It studies about women's awareness and also shows the rejection of the traditional concepts. It reveals a woman's capacity to asset her own rights and individuality and become fully aware of her potential as a human being.

In the novel, the protagonist Sarita very boldly faces upto the veracity and comprehends that, the dark now longs hold any terror to her. She is usually known and recognized as 'Saru'. She is an ordinary, simply, modest, sensitive, middle class women who is aware of her own limitations, but lacks self confidence. She wished and hoped and always longed to break away from the rigid traditional norms. She yearns for a new environment where, the mother cannot thrust her will on her daughter. Due to unhealthy experiences at her parental home, leads her to ascertain the unseen reserved potency in an individual, that at times leaps up to help the individual by shaping life into a pleasurable and a possible one. 
The narrator narrates the story in the flash back technique. The story is of a marriage on the rocks. The novel discusses on the sensitive concept of 'bounding and bondage' which are considered quite vital in understanding women's situation worldwide. In the novel, the protagonist Sarita is a successful doctor during the daytime; and at night a terrified and trapped animal in the hands of her husband, Manohar who is an English teacher in a small college.

The novel begins with Sarita (Saru) coming to her father's house after fifteen years of marriage. She had once determined and had declared that in no way she would return to her father's place. But, now she comes to her father's place unable to bear the sexual sadism of her husband. Her stay in her father's house gives Sarita an opportunity to assess her bond with her father, husband and her dead mother. Now, she can understand better of herself and others. The rest of the novel is what Saru remembers all the past, a brief confession to her father about her trauma and her courage to confront reality.

The novel exhibits the trauma of a girl-child who has suffered the bullying and curtailment of activity by her mother. The girl- child Saru grows up as a victim of her mother sexist and gender-based bias; which further reduces her later life into a desperate struggle to overcome the initial victimization, in order justify her decisions to her mother who no longer acknowledges her as a daughter, and to find out a new meaning to her life which could enable her to develop and nurture a balanced perspective towards her diversified roles as a mother, as a wife, and as a career woman. Apart from the other problems that are faced by a woman in today's male chauvinist society, the strange mother-daughter relationship is centrally significant component in understanding of this novel.

Saru's mother is full of a closed psyche traditionalist society, has instilled an ethical bond to choose a son; and the daughter, yet to come to terms to her mother's diktat about her secondary place/status in the family. Saru's mother never pardon her daughter Saru for being alive even after her brother had drowned, and she coned nor forget the alarming effect of her mother's frenzied outbreak. Even, Saru fails to get any sympathy from her father, and this guilt suffocates her, and she is made to live with the guilt that she was the murderer. She remembers the conversation between her and her mother when Dhruva died as - 
"You did it, you did this, you killed him... you killed him. I didn't. I didn't know. I never saw him. Why didn't you die? Why are you alive, when he's dead?" (The Dark Holds No Terrors 191)

The words follow her for days, months, years, and all her life. Her mother saddle's the girl child with all the equipments of being traditional women like her. Thinking that it's a traditional bound life, her daughter would be quite safe. But, sometimes, the mother can also be cruel and hostile towards her own daughter, and treats her with a sense of rivalry. The hostile chauvinistic societal environments, has molded the psyche of a mother as a woman, and also make the young uninitiated girl child a special object of the mother's persecution. Society treats the male-child, the son as an eventual solution to all problems, the girl, and the daughter is always treated as an unwanted burden, as she cannot fulfill, the parental needs or ungratified ambitions without the given social calculus. In normal circumstances the warmth and value given to a make-child is denied to the girl-child naturally making her either depressed or rebellious. If this negative and destructive social treatment is not countered by the warmth and adoring heed of her mother, the daughter is totally denounced to a life of resentment leading to lose sight of the implacable grandeur of life.

After her brother's death, the family glides into an everlasting lamenting and there are no celebrations. Saru, very vividly remembers her fifteenth birthday. Her friend Smita presents her a pair of earrings, which, she keeps them secretly and wears them only when she is away from the home. Saru knows that her friend's gift would not be approved off. Her mother too, gives her a pair of earrings, but Saru spurns this gift because, she thinks that it was given under obligations and her feelings were not important to her mother. Saru feels that the gift was not for her, -

"So that was it! It was not for me, not to please me and make me happy, but because I should, as a growing girl, have these things to wear- I don't want them, I don't want to eat, I don't want anything" (171).

Her experiences at home have made her to discover inferiority in herself as a fixed and pre ordained essence. Sarita's mother treated her as an adult rival in her adolescence so her relationship with her mother had always dominated by her. Saru's fifteenth birthday illustrates the 
bitter contradiction between her mother and herself; the mother usually and always likes to rule alone over her feminine universe; she wants to be unique, irreplaceable. When Saru went for a walk her mother says -

“A walk? Such a long time? Don't you know it's dark...? Didn't you think you could have helped me at home? There are vegetables to be cut, the buttermilk to be churned'.

Saru put up with gendered discrimination, typically common to the Indian middle class Society. The society, which has imposed unjust gender discrimination, is not at all questioned by Saru's mother, she has been told and taught to rear a girl in a particular fashion and she does it with implicit faith. Being herself a victim of social conditioning she is able to perceive the cruelty, which she is perpetuating. Right from the beginning Saru is made to understand that she is a girl and she is inferior to her brother, in every way.

"Don't go out in the sun you'll get even darker. Who cares? We have to care if you don't; we have to get you married, I don't want to get married. Will you live with us all your life? Why not? You can't And Dhruva? He's different. He's a boy"(45).
The socio-cultural conditioning of a girl is still a part of Indian culture, hence Saru's lively, full of life, is gradually suffocated by her mother's constant criticism and fault finding. Saru is always made to feel ugly, unwanted and undesirable. Her mother had felt that physical beauty is a precondition of worldly success, for a girl and constantly criticizes her daughter's appearance. Sarita gets back from her mother a picture of ugliness. As Sarita says - "I was an ugly girl, At least, my mother told' me so". Saru's mother says - "You should be careful now about now you behave" (61). it is clear that the mother had bounced back the own ugliness and Saru spontaneity had been married to the life negation.

On account of thin intricate web of her inner landscape, of thin intricate web of her inner landscape, sari emerges as ad, yet a lively girl. At once she is a befuddled child, desperately seeking the assurance of her parents, particularly of her mother. She feels quite lost in the delicate web of emotions and gets shattered and quite humiliated when the parents fail to show any kind of emotions towards her. Flabbergasted, bitby-bit, she builds a beerier of hostile silence around her. The shadows of her 
unhappy relationship with her mother darken her adolescence, her early youth, and for that matter even her first love.

Later, in her life, at every success, she hesitates and wants to turn back, as if to seek her mother's approval, and as if to tell her that despite everything she has done to her, she is happy and successful. Beneath, her strong wanton defiance lies a lonely, shivering and in secured girl, who wants to be accepted, loved \& cherished by someone, only because this lovely, unsecured girl had always been spurned and rebuffed by her mother. Thus, her love for Manohar is lingering with this feeling of insecurity.

Saru marries Manohar quite distressed her parent with, she doesn't feel any regret at this separation but her childhood distressing experience still disturbs her. Instead of getting her troubles solved after her marriage, her troubles get strengthened by the male bigoted thoughts, opinions; attitudes of the society influence the husband - wife rapport. After her marriage, Manohar and Saru trek not only in distinctive tracks but even in contrary tracks. Saru's journey is from being a nonentity to become an entity. After getting first degree in medicine, completes, attends private patients and finally has a clinic of her own. She achieves each of this on her own, without any support from her husband or father.

The novel deals with the man-woman relationship within the institution of marriage in our contemporary society, as a sub-theme. Shashi Deshpande discusses several problems related with women, marriage and tradition. Many a times, the insipidly marriage kills the couple slowly, but more so, the woman is the worst' sufferer. There is Saru's friend Smita, had to change her name and had to depend upon her husband absolutely. She had no freedom to spend money according to her desire, and always borrows money from Saru. Saru ultimately realizes that marriage is not a guarantee of happy fulfillment.

Marriages normally subordinate the wives to the husband and it also idealizes female martyrdom. There is a slight disparity with Manohar, for he had a joyful childhood, $\mathrm{He}$ is a handsome man; he is a poet, an orator, director of plays and a sect figure. After marrying, Saru begins to enjoy better economical and communal position. Both enjoy an amicable association so far as Saru was only his wife. But after she thinks the position of a lady doctor and that he is documented as her husband, the equation alters, he becomes an envious; sexually hostile 
husband. A woman should know that success in marriage means manipulating, sacrificing, adjustments and silently maneuvering her relationship with her husband according to the socially accepted norms. All her intellect, her carrier, her achievement, her ambitions-in case supersedes her husband, then, she must understand that they are the stigmas and she will have to carry like black mark forever. Manohar's sense of inferiority changes him into a sadist, who gets pleasure by insulting his wife, harassing and hurting her. At the initial stage, Saru cannot oppose, because, her mother had moulded her psyche to accept drudgery and self-negation as a norms of routine existence for a married woman and to treat herself as an undesirable person in a subconscious manner. Now, her passions are a mixture of objective and analytical understanding if her own past, imparting a cohesive. Once again Saru mentally travels all the bitter experiences she had experienced will her mother, she realizes that one has to growing to know 'The Dark Holds No Terror', that.

"The terrors those within us, and like traitors they spring out, when we last expect them, to scratch and maul" (Woman In The Novels Of Shashi Deshpande - A Study 10).
One has to slay or defeat the mysterious phantoms that trouble us. Saru agrees to her solitude and endeavor to triumph over it by-

“All right, so I'm alone. But so's everyone else. Human beings - They're going to fail you. But because there are just us because there's none else we have to go on trying. If we can't believe in ourselves, we're sunk" (The Dark Holds No Terrors 220)

Understanding to reshape her life and would her fate. She comes to believe that all is not, that has been exhausted. There is still to be faced, and hence her struggle towards a mere constructive nature holds on life to survive. She recognizes that she has to brawl out with the darkness herself; no one can assist her absence, so as to live without panic she will have to look into the face of veracity and tackle with it on her own.

The novel discusses on the sensitive concept of 'bounding' and 'bondage' is considered quite vital in understanding women's situation worldwide. A woman in the social sphere only amounts to total possession of her cadaver by men. Thus this cadaver today has emerged as an important site for study in feminist discourse. The real problem lies in liberating the female cadaver from 
domination and subjugation in the area of social and ethical values. Shashi Deshpande, no doubt gives a vivid concept of this even though this is not the central focus of the novel but becomes central of the novel in the depiction of love, pain and death, as different aspects of the cadaver.

The protagonist Sarita is highly self-willed and her ego and innate love for power over others multiply her problems. She marries against her parents became she felt in secure in her parents' home. Her marriage with Manohar at one stage was for security and love. As a doctor she is successful and becomes quite busy which ultimately upsets her family life. Her husband is quite annoyed with her popularity and her busy life unable to give enough attention at the domestic front. She finds herself placed at, her personal level, she feels gradual disappearance of love and family attachment, she is a wife $\&$ a mother unable to devote her time to her husband needs and children. Here she fails first as a wife and secondly as a mother.

Her feeling of loneliness is her inner disintegration. This disintegration is due to her ego and will to dominate others. Economic freedom and Education based on money power and social status have set in a new set of values in her life. Her disintegration has to become integration in order to have a family life. She has to accept her life as it is along with her children, her husband and her duties.

The real solution to the darkness in her life is not escapism or cursing the darkness. Sarita has to light a candle and declare for herself that The Dark Holds No Terrors. The real darkness is in her mind, and when this darkness lifts from her mind, she will see the reality clearly. The message of the novel - the fear of losing oneself in the dark labyrinthine passages of this mysterious world is dispelled, if a woman understands that she will have no refuge in any relationship unless she believes in her own self and accepts the responsibilities of her own life.

\section{WORKS CITED:}

[1] Deshpande Shashi, The Dark Holds No Terrors, Penguin Books. New Delhi: 1990. Print.

[2] Sathupati Prasanna Sree, Woman In The Novels Of Shashi Deshpande - A Study, Sarup \& Sons. New Delhi: 2003. Print. 
[3] Naik Chanchala.K, Writing Difference; The

Novels of Shashi Deshpande, Pen craft

International. New Delhi:2005. Print.

[4] K.R. Srinivasa Iyenger. Indian writing in

English, Sterling Publishers. New

Delhi:1993. Print. 